\title{
Isolasi dan Identifikasi Senyawa Metabolit Sekunder Ekstrak Aseton Daun Tumbuhan Tembelekan (Lantana camara Linn.)
}

\section{Isolation and Identification of Secondary Metabolite Compound in Acetone Extract of Tembelekan Leaves (Lantana camara Linn.)}

\author{
${ }^{1)}$ Rosni Kotala, ${ }^{2)}$ Diana Eka Pratiwi, ${ }^{3)}$ Ramdani \\ 1,2,3) Jurusan Kimia Fakultas Matematika dan Ilmu Pengetahuan Alam \\ Universitas Negeri Makassar, Jl. Dg Tata Raya Makassar, Makassar 90224 \\ Email: rosnikotala@gmail.com
}

\begin{abstract}
ABSTRAK
Penelitian ini adalah penelitian eksplorasi yang bertujuan untuk mengisolasi dan mengidentifikasi senyawa metabolit sekunder dari ekstrak aseton daun tumbuhan tembelekan (Lantana camara Linn.). Daun tumbuhan ini diperoleh dari Kabupaten Wajo, Sulawesi Selatan. Penelitian dilakukan melalui beberapa tahap yaitu preparasi sampel, maserasi dengan aseton, fraksinasi, pemurnian, dan identifikasi. Isolat yang diperoleh berbentuk serbuk berwarna putih yang terdekomposisi pada suhu $2220 \mathrm{C}$ dan uji pereaksi menunjukan hasil positif pada pereaksi LiebermanBuchard. Data dari hasil Spektrum FTIR menunjukkan pada bilangan gelombang $3126.61 \mathrm{~cm}-1$ mengandung gugus hidroksil $(\mathrm{OH})$, alkil $(\mathrm{CH} 2$ dan CH3) pada bilangan gelombang 2956,80 cm-1 ,C-O alkohol sekunder pada bilangan gelombang $1039.63 \mathrm{~cm}-1$ dan alkena $(C=C)$ tak terkonjugasi pada bilanagan gelombang 1678,07 cm-1. Berdasarkan uji titik leleh, uji pereaksi serta data spektrum FTIR isolat diduga senyawa steroid yang termasuk golongan sterol (steroid alkohol).

Kata kunci : Lantana camara Linn., Isolasi, Aseton, Sterol
\end{abstract}

\begin{abstract}
This exploratory research aimed to isolate and identificate the secondary metabolite compound in aceton extract of tembelekan leaves (Lantana camara Linn.). Samples were obtained from Wajo regency, South Sulawesi. This research was conducted in several steps; preparation, maceration with acetone, fractionation, purification, and identification. The result obtained pure isolate form white powder, melting point of $2220 \mathrm{C}$ and reagent test showed positive of Burchard Lieberman. Data spectrum of FTIR showed wave number (cm-1) of $3126.61 \mathrm{~cm}-1$ as a hydroxyl group $(\mathrm{OH})$, alkyl ( $\mathrm{CH} 2$ and $\mathrm{CH} 3)$ at wave number $2956.80 \mathrm{~cm}-1, \mathrm{CO}$ secondary alcohols at wave number $1039.63 \mathrm{~cm}-1$ and alkene $(\mathrm{C}=\mathrm{C})$ unconjugated at wave number of $1678.07 \mathrm{~cm}-1$. Based on the melting point test, reagent test and FTIR spectrum data showed that the isolate steroid compound as sterol group (alcohol steroid).
\end{abstract}

Keywords : Lantana camara Linn., Isolation, Acetone, Sterols 


\section{PENDAHULUAN}

Hutan tropis Indonesia mempunyai tumbuh-tumbuhan yang perannya dalam era teknologi tidak kalah pentingnya dengan Sumber Daya Alam (SDA) lainnya seperti gas, batu bara, mineral dan lain-lain. Dari segi ilmu kimia, SDA hayati ini merupakan sumber-sumber senyawa kimia yang tak terbatas jenis maupun jumlahnya. Dengan demikian keanekaragaman hayati dapat diartikan sebagai keanekaragaman kimiawi yang mampu menghasilkan bahan-bahan kimia baik untuk kebutuhan manusia maupun untuk organisme lain seperti untuk obat-obatan, insektisida, kosmetik dan sebagai bahan dasar sintesa senyawa organik yang lebih bermanfaat. Pengobatan secara tradisional sebagian besar memanfaatkan ramuan berasal dari tumbuh-tumbuhan baik berupa akar, kulit batang, daun, bunga, atau bijinya.

Salah satu tumbuhan tropis Indonesia yang sudah lama digunakan masyarakat sebagai obat ramuan tradisional adalah Verbenaceae yang merupakan salah satu famili yang cukup besar, terdiri atas 100 genus dan sekitar 2600 spesies. Tanaman ini dipercaya berkhasiat sebagai obat antiradang dan hemostatis. Bunga dan daun dapat mengobati penyakit bisul dan koreng, diuretik, sedatif, (Rumondang, 2004). Spesies lain yang biasa digunakan oleh Suku Maybrat di Papua sebagai obat tradisional yaitu Callicarpa sp., dan Premna corymbosa. Spesies C. glabrum memiliki bioaktivitas sebagai antimikrobial yang baik karena memiliki komponen kimia seperti polifenol, glikosida, saponin, dan steroid pada daun (Masevhe, 2013).
Penelitian yang telah dilakukan oleh Ghisalberti (2000), bahwa L. camara Linn. memiliki efek sebagai larvasida alami. Daun dan bunga tembelekan mengandung alkaloid, flavonoid, saponin, tannin, dan kuinon. Ekstrak metanol kasar dari akar L. camara Linn. mengandung senyawa terpenoid yang mempunyai aktivitas antibakteri yang baik terhadap Salmonella paratyphi dan Vibrio cholera, dan dari daun memiliki efek toksit yang relatif tinggi sehingga berpotensi sebagai antitumor (Remya et al., 2013). Sebagaimana juga telah ditemukan Wardani et al., (2010), salah satu bahan alami yang aman dan dapat digunakan sebagai insektisida nabati untuk larvasida adalah ekstrak daun Tembelekan. Daun L. camara Linn. mengandung minyak atsiri, alkaloid, saponin, flavonoid, dan tanin. Berdasarkan uraian di atas, diketahui bahwa tumbuhan L. camara Linn. memiliki beragam khasiat karena adanya senyawa-senyawa yang dikandungnya, sehingga peneliti menganggap perlu diadakan suatu penelitian lebih lanjut untuk mengkaji kandungan senyawa metabolit sekunder dari ekstrak aseton pada daun tumbuhan L. camara Linn.

\section{METODE PENELITIAN}

\section{A. Alat dan Bahan}

Alat-alat yang digunakan pada penelitian ini di antaranya corong Buchner, alat-alat gelas yang umum digunakan, wadah maserasi, botol fial, chamber sebagai wadah KLT, pipa kapiler, pinset, hot plate, alat kromatografi cair vakum, oven, gunting, lampu UV $254 \mathrm{~nm}$, neraca analitik, 
evaporator, batang pengaduk, alat penentuan titik leleh, spektroskopi IR.

Bahan-bahan yang digunakan dalam ekstraksi dan identifikasi di antaranya, serbuk halus daun L. camara Linn., kertas saring, aquadest, beberapa pelarut organik teknis seperti n-heksana $96 \%$, etil asetat $96 \%$, metanol $96 \%$, aseton 96\%, kloroform 96\%, reagen penampak bercak noda LiebermannBuchard, Dragendorff, Wagner, Mayer, serium sulfat $\left(\mathrm{CeSO}_{4}\right) 10 \%$, besi (III) klorida $\left(\mathrm{FeCl}_{3}\right)$ 1\%, kertas saring Whatman, kertas saring biasa, aluminium foil, tissue, silika gel G 60, pelat KLT aluminium berlapis silika gel G $60 \mathrm{GF}_{254}$ dan tissue.

\section{B. Prosedur Kerja}

\section{Persiapan Bahan Sampel}

Daun L. camara Linn. yang telah diambil dibersihkan dengan air, kemudian dikeringkan dengan cara diangin-anginkan kemudian dipotong kecil-kecil dan dihaluskan menggunakan blender hingga didapatkan sampel yang berbentuk serbuk, serbuk kemudian ditimbang sebanyak 2,4 kg.

\section{Ekstraksi Dan Fraksinasi Sampel \\ a) Ekstraksi}

Serbuk halus daun L. camara Linn. sebanyak 2,4 $\mathrm{kg}$ dimaserasi dengan aseton selama kurang lebih $3 \times 24$ jam. Selanjutnya disaring menggunakan corong Buchner sehingga diperoleh ekstrak aseton. Ekstrak aseton yang diperoleh diuapkan dengan evaporator pada suhu $40^{\circ} \mathrm{C}$ sampai diperoleh ekstrak kental aseton. Maserat yang diperoleh dilakukan uji pendahuluan dengan pereaksi Liebermann-buchard (terpenoid dan steroid), $\mathrm{FeCl}_{3}$ (flavonoid), Meyer (alkaloid) dan Wagner (alkaloid), selanutnya diuji dengan KLT.

\section{b) Fraksinasi}

Ekstrak kental aseton yang terdiri dari beberapa komponen tersebut difraksinasi dengan metode kromatografi kolom cair vakum. Hasil KKCV yang diperoleh diuapkan pada suhu ruangan.

\section{c) Pemurnian}

Komponen padatan yang diperoleh direkristalisasi dengan cara didekantasi dengan menggunakan pelarut aseton. Kemurnian senyawa yang diperoleh ditentukan dengan melakukan KLT sistem tiga eluen dengan menggunakan n-heksana : etil asetat (9:1), n-heksana : kloroform (1:9), dan kloroform : etil asetat (9:1).

\section{d) Identifikasi}

Isolat tunggal yang sudah murni dilakukan uji pereaksi seperti Liebermann-Burchard, Wagner, Dragendroff dan Mayer untuk mengetahui golongan senyawa metabolit sekunder yang diperoleh. Identifikasi lebih lanjut dilakukan dengan alat spektrometer FTIR.

\section{HASIL DAN PEMBAHASAN}

\section{A. Hasil Penelitian \\ 1. Uji Golongan}

Ekstrak kental aseton daun L. camara Linn. yang diperoleh diuji warna dengan menggunakan pereaksi seperti $\mathrm{FeCl}$, Lieburmann-Buchard, Mayer dan Wagner. Hasil uji sebagaimana pada Tabel 1. 
Tabel 1. Hasil Uji Pendahuluan Ekstrak Aseton

\begin{tabular}{clc}
\hline Pereaksi & Pengamatan & Keterangan \\
\hline \multirow{2}{*}{$\mathrm{FeCl}_{3}$} & $\begin{array}{l}\text { hijau } \rightarrow \\
\text { kuning } \\
\text { kehijauan }\end{array}$ & $\begin{array}{c}(+) \\
\text { Flavonoid }\end{array}$ \\
\hline LB & hijau $\rightarrow$ Biru & $(+)$ Steroid \\
\hline \multirow{2}{*}{ Meyer } & $\begin{array}{l}\text { hijau } \rightarrow \\
\text { kuning } \\
\text { kecokelatan }\end{array}$ & $\begin{array}{c}(+) \\
\text { Alkaloid }\end{array}$ \\
\hline \multirow{2}{*}{ Wagner } & $\begin{array}{l}\text { hijau } \rightarrow \\
\text { cokelat, } \\
\text { endapan } \\
\text { cokelat }\end{array}$ & $\begin{array}{c}(+) \\
\text { Alkaloid }\end{array}$ \\
\hline
\end{tabular}

2. Fraksinasi

Sebelum difraksinasi ekstrak aseton terlebih dahulu diuji secara kromatografi lapis tipis (KLT). Hasil KLT yang diperoleh pada kombinasi eluen n-heksana : etil asetat (8:2) menunjukkan pola pemisahan noda yang baik dan jelas.

Proses fraksinasi dilakukan secara bergradien dimulai dari n-heksana $100 \%$, n-heksana : etil asetat (9:1 sampai 1:9), etil asetat $100 \%$, etil asetat: aseton (9:1;7:3;5:5;3:7;1:9), aseton $100 \%$, aseton:metanol (9:1 sampai 1:9) dan metanol 100\%. Dari hasil KKCV diperoleh 37 fraksi.

Fraksi 1-37 yang diperoleh dari hasil KKCV diidentifikasi melalui kromatografi lapis tipis (KLT) dengan kombinasi eluen $n$ - heksana : etil asetat pada perbandingan $(8: 2 ; 2: 8 ; 5: 5)$, nheksana $100 \%$, dan etil asetat $100 \%$, dimana fraksi-fraksi yang memiliki pola kromatogram yang sama digabung ke dalam satu fraksi gabungan, sehingga diperoleh 17 fraksi.
Fraksi 12 (e) berupa isolat berbentuk padatan berwarna hijau dengan berat 0,5224 gram. Selanjutnya isolat tersebut didekantasi menggunakan pelarut aseton. Setelah didekantasi dengan pelarut aseton dan diperoleh isolat berbentuk serbuk berwarna putih dengan berat 0,154 gram.

\section{Uji Kemurnian}

Isolat yang diperoleh diuji kemurniannya dengan metode sistem tiga eluen dan uji titik leleh. Adapun tiga jenis eluen yang digunakan yaitu (a) nheksana : kloroform (1:9); (b) n-heksana : etil asetat (9:1) dan (c) kloroform : etil asetat(9:1) hasil yang diperoleh berupa noda tunggal pada plat KLT menunjukkan bahwa isolat yang diperoleh telah murni secara KLT. Selanjutnya uji titik leleh menggunakan Melting Point SMPII diperoleh titik leleh isolat $222^{\circ} \mathrm{C}$. Adapun kromatogram dari isolat yang di uji sistem tiga eluen dapat dilihat pada Gambar 1.

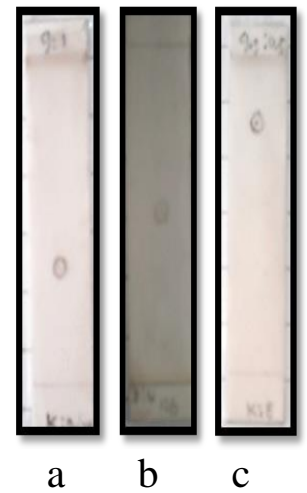

Gambar 1. Kromatogram Fraksi 12 (E) Hasil KLT dengan Sistem Tiga Eluen Adsorben: silika gel $\mathrm{G} 60 \mathrm{~F}_{254}$ Eluen: a) n-heksana: Kloroform (1:9)

b) n-heksana: etil asetat $(9: 1)$

c) kloroform: etil asetat $(9: 1)$ 


\section{Identifikasi}

\section{a. Uji Golongan}

Isolat yang diperoleh dilakukan uji pereaksi Wagner, Meyer, $\mathrm{FeCl} 3$ 1\%, dan Liebermann-Burchard. Hasil uji golongan isolat fraksi 12 (E) dengan pereaksi Liebermann Burchard menunjukkan hasil positif steroid dengan perubahan warna dari larutan bening menjadi hijau.

\section{b. Uji Spektroskopi}

Pengujian dilanjutkan dengan menggunakan alat spektroskopi FTIR. spektrometer FTIR yang dilakukan dengan teknik pellet $\mathrm{KBr}$ pada rentang bilangan gelombang $4500-500 \mathrm{~cm}^{-1}$. Berikut ini adalah serapan IR dari isolat yang ditunjukkan pada Gambar 2.

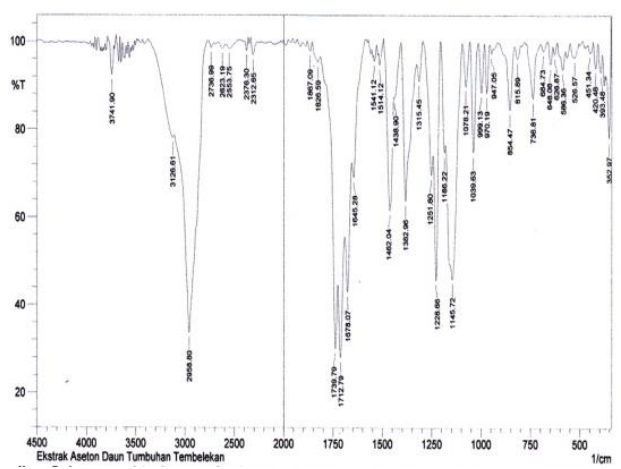

Gambar 2. Serapan IR Isolat Fraksi $12(\mathrm{E})$

\section{B. Pembahasan}

\section{Tahap Preparasi Sampel dan Ekstraksi}

Tumbuhan L. Camara Linn. yang dijadikan sampel merupakan tumbuhan yang masih segar yang diambil langsung dari pohonnya. Tumbuhan L. Camara Linn. dibersihkan dan dikeringkan dengan cara diangin-anginkan tanpa terkena cahaya matahari langsung.
Sampel yang sudah kering dihaluskan menggunakan blender dan diperoleh serbuk halus.

Proses ekstraksi dilakukan dengan maserasi mengunakan pelarut aseton. Hasil maserasi menghasilkan maserat yang berwarna hijau pekat dan disaring dengan menggunakan corong Buchner dan kertas saring Whatman. Ekstrak aseton dievaporasi untuk menguapkan pelarutnya dengan menggunakan vacum rotary evaporator pada suhu $40^{\circ} \mathrm{C}$.

\section{Uji Golongan}

Ekstrak kental aseton yang diperoleh dilakukan uji Pereaksi seperti Lieberman - Burchard untuk mengidentifikasi adanya steroid terpenoid, pereaksi Wagner dan meyer untuk menguji adanya senyawa golongan alkaloid, dan pereaksi $\mathrm{FeCl}_{3} 1 \%$ untuk menguji adanya golongan flavonoid.

\section{a. Uji alkaloid}

Hasil pengamatan menunjukkan bahwa ekstrak aseton daun L. camara Linn. memberikan hasil berupa endapan coklat pada uji Wagner yang mengindikasikan adanya senyawa alkaloid. Sebagaiman juga pada uji Mayer memberikan warna kuning kecoklatan yang mengindikasikan adanya senyawa golongan alkaloid jenis yang lain yang terdapat pada ekstrak aseton daun L. camara Linn. sehingga senyawa ini kemungkinan besar ada yang terekstrak dalam pelarut polar seperti aseton.

\section{b. Uji flavanoid}

Hasil pengamatan menunjukkan bahwa ekstrak aseton daun L. camara Linn. memberikan hasil berupa 
perubahan warna larutan dari hijau menjadi hijau kehitaman dan terdapat endapan hijau yang mengindikasikan adanya senyawa fenolik.

\section{c. Uji Steroid}

Ekstrak aseton daun L. camara Linn. memberikan hasil berupa warna biru. Hal ini mengindikasikan adanya senyawa steroid yang umumnya bersifat nonpolar sehingga senyawa ini kemungkinan besar terekstrak dalam pelarut polar seperti aseton.

\section{Fraksinansi}

Proses fraksinansi dilakukan dengan cara kromatografi kolom Kolom Cair Vakum (KKCV), mulai dari eluen non polar sampai polar. Hasil yang diperoleh dari KKCV sebanyak 37 fraksi. Selanjutnya dilakukan uji kromatografi lapis tipis (KLT) dengan kombinasi eluen n- heksana : etil asetat (8:2), (5:5), dan (2:8), n-heksana 100\% Fraksi-fraksi dengan kromatogram sama digabungkan hingga diperoleh 17 fraksi gabungan. Fraksi gabungan hasil KKCV yang diperoleh kemudian diuapkan sampai menguap seluruhnya. Fraksi 12 (e) sebanyak 0,5224 gram yang berbentuk padatan berwarna hijau adalah fraksi yang dipilih dan dilanjutkan untuk dilakukan dekantasi yaitu dengan melarutkan zat- zat pengotor yang masih terdapat dalam padatan tersebut tanpa melarutkan padatan yang sudah ada. Hasil yang diperoleh yaitu isolat berbentuk serbuk berwarna putih dengan bobot sebanyak 0,154 gram.

\section{Identifikasi}

Isolat yang diperoleh kemudian diuji kemurnianya dengan metode KLT sistem tiga eluen dengan pelarut dan perbandingan yang berbeda. Isolat selanjutnya dilakukan pengujian titik leleh. Hasil yang diperoleh menunjukan isolat murni mulai pertama meleleh pada suhu $220^{\circ} \mathrm{C}$ dan meleleh secara keseluruhan pada suhu $222^{\circ} \mathrm{C}$.

\section{Uji Spektroskopi}

Isolat yang diperoleh dilakukan analisis menggunakan spektrometer infra merah (IR). Pengamatan menunjukkan bahwa daerah serapan IR pada isolat menunjukkan adanya beberapa gugus fungsi. Pita serapan $3126.61 \mathrm{~cm}^{-1}$ merupakan vibrasi ulur dari $\mathrm{OH}$ dugaan ini diperkuat oleh adanya serapan dari regangan $\mathrm{C}-\mathrm{O}$ alkohol sekunder siklik pada daerah $1039.63 \mathrm{~cm}^{-1}$. Pita serapan ini menunjukkan bahwa senyawa isolat merupakan suatu senyawa siklik (steroid) yang mengandung gugus $\mathrm{OH}$. Selanjutnya pita serapan 2956,80 $\mathrm{cm}^{-1}$ merupakan vibrasi ulur dari $-\mathrm{CH}$ regang yang diperkuat oleh adanya gugus metil dan metilena diperkuat dengan adanya vibrasi tekuk $-\mathrm{CH}_{2}-$ dan $-\mathrm{CH}_{3}$ pada daerah $v$ 1228,66 dan 1145,72 $\mathrm{cm}^{-1}$ yang mengindikasikan adanya gugus geminal dimetil $-\mathrm{CH}\left(\mathrm{CH}_{3}\right)_{2}$ sebagai ciri khas senyawa triterpenoid/steroid.

Adanya serapan tajam dengan intensitas lemah pada daerah $v 1678,07$ $\mathrm{cm}^{-1}$ mengindikasikan adanya vibrasi ulur $\mathrm{C}=\mathrm{C}$ non konjugasi $\left(1620-1680 \mathrm{~cm}^{-}\right.$ $\left.{ }^{1}\right)$. Dugaan ini diperkuat dengan adanya vibrasi tekuk $=\mathrm{C}-\mathrm{H}\left(1000-650 \mathrm{~cm}^{-1}\right)$ luar bidang pada daerah $v 854,47 \mathrm{~cm}^{-1}$. Selanjutnya pita serapan pada daerah serapan 1739.79 dan $1712,799 \mathrm{~cm}^{-1}$ merupakan daerah serapan $\mathrm{C}=\mathrm{O}$, daerah $1462,04 \mathrm{~cm}^{-1}$ menunjukkan ikatan $\mathrm{C}=\mathrm{C}$ aromatik. 
Data posisi serapan bentuk pita, intensitas dan karakteristik serapan dari spektrum infra merah isolat fraksi $12(\mathrm{E})$ dapat dilihat pada Tabel 2.

Tabel 2. Data perbandingan Spektrum FTIR Isolat Fraksi 12 (E) dengan Literatur

\begin{tabular}{|c|c|c|c|}
\hline \multicolumn{2}{|c|}{ Pita serapan FTIR $\left(\mathrm{cm}^{-1}\right)$} & \multirow{2}{*}{$\begin{array}{c}\text { Bentuk } \\
\text { pita }\end{array}$} & \multirow{2}{*}{ Gugus fungsi } \\
\hline Isolat & Pustaka & & \\
\hline 3125,61 & $3500-3300 * * *$ & $\begin{array}{l}\text { Sedikit } \\
\text { Melebar }\end{array}$ & $\mathrm{O}-\mathrm{H}$ \\
\hline 2956,80 & $2900-2850 * * *$ & Tajam & $\begin{array}{l}\mathrm{C}-\mathrm{H} \text { pada } \mathrm{CH}_{3} \text {, dan } \\
\mathrm{CH}_{2} \text { ulur }\end{array}$ \\
\hline $\begin{array}{l}1739,79 \\
; 1712,79\end{array}$ & $1750-1720 * *$ & Tajam & $\mathrm{C}=\mathrm{O}$ \\
\hline 1678,07 & $1710-1700 * * *$ & Tajam & $\mathrm{C}=\mathrm{C}$ (non-konjugasi) \\
\hline $\begin{array}{c}1462,06 \\
1382,98\end{array}$ & $1400-1390 * *$ & Tajam & $\mathrm{C}=\mathrm{C}$ aromatik \\
\hline 1039,63 & $900-890 * * *$ & Tajam & C-O alkohol \\
\hline 854,47 & $765-755^{*}$ & Tajam & $=\mathrm{C}-\mathrm{H}$ \\
\hline
\end{tabular}

Berdasarkan interpretasi data spektrum FTIR jika dilihat dari beberapa gugus fungsinya isolat faraksi 12 diperkirakan mengandung senyawa golongan steroid yaitu sterol ( steroid alkohol) dimana adanya gugus hidroksil, gugus alkil, dan ikatan rangkap yang tidak berkonjugasi.

\section{KESIMPULAN DAN SARAN}

\section{A. Kesimpulan}

Berdasarkan hasil penelitian yang diperoleh, maka dapat ditarik kesimpulan bahwa hasil senyawa yang diperoleh dari ekstrak aseton daun tumbuhan tembelekan (L. Camara Linn.) adalah salah satu senyawa bahan alam yang tergolong sterol. Hal ini didukung oleh adanya reaksi positif terhadap isolat dengan pereaksi Liebermann-Burchard yakni memberikan warna hijau. Isolat yang diperoleh berbentuk serbuk berwarna putih ini memiliki titik leleh $220-222^{\circ} \mathrm{C}$.

\section{B. Saran}

Adapun hal-hal yang disarankan berkaitan dengan penyempurnaan penelitian ini adalah sebagai berikut:

1. Perlu dilakukan karakterisasi lebih lanjut untuk menentukan struktur senyawa dari isolate yang diperoleh.

2. Mengingat masih banyak fraksi yang tidak dilanjutkan untuk itu perlu dilakukan penelitian lanjutan terhadap fraksi-fraksi hasil KKCV yang lainnya agar dapat diperoleh senyawa metabolit sekunder yang lain.

\section{DAFTAR PUSTAKA}

Fitriani. 2013. Isolasi dan Uji Aktivitas Senyawa $\beta$-sitosterol dari Kulit Batang Kleinhovia hospita 
Linn. Skripsi. Makassar: Sastrohamidjojo, Hardjono. 1992. Universitas Negeri Makassar. Spektroskopi Inframerah. Yogyakarta: Liberty.

Ghisalberti, E.L. 2000. Lantana camara L. (Verbenaceae). Department of Chemistry, University of Western Australia, Nedlands, Western Australia 6907, Australia. Fitoterapia 71: 467486.

Masevhe, N.A. 2013. Isolation and Characterization of Antifungal Compounds from Clerodendron glabrum var glabrum (Verbenaceae) Used Traditionally to Treat Candidiasis in Venda, South Africa. Pretoria, University of Venda.

Saleh, C., dan Pramana Riza Agus, M., 2013. Isolasi dan karakterisasi Senyawa Steroid pada Fraksi NHeksan Dari Daun Kukang (Lepisanthes Amoena( HASSK.) LENNH.) Leaves. Jurnal Kimia Mulawarman. Vol.10. No.2.

Wardani, R.S., Mifbakhuddin \& K. Yokorinanti. 2010. pengaruh konsentrasi daun tembelekan (lantana camara L.) terhadap kematian larva aedes aegypti. J Kesehat Masy Indones. Vol. 6. No.2.

Rumondang, B. 2004. Lantaden XR Glikosida dari Daun Lantana camara L. jurnal matematika dan SAINS. vol. 9. No.1. 